University of Michigan Law School

University of Michigan Law School Scholarship Repository

Law \& Economics Working Papers

$11-1-2012$

\title{
Double or Nothing: A Tax Treaty for the 21st Century
}

Reuven S. Avi-Yonah

University of Michigan Law School, aviyonah@umich.edu

Oz Halabi

University of Michigan Law School, ozh@umich.edu

Follow this and additional works at: https://repository.law.umich.edu/law_econ_current

Part of the Tax Law Commons

\section{Working Paper Citation}

Avi-Yonah, Reuven S. and Halabi, Oz, "Double or Nothing: A Tax Treaty for the 21st Century" (2012). Law \& Economics Working Papers. 66.

https://repository.law.umich.edu/law_econ_current/66

This Article is brought to you for free and open access by University of Michigan Law School Scholarship Repository. It has been accepted for inclusion in Law \& Economics Working Papers by an authorized administrator of University of Michigan Law School Scholarship Repository. For more information, please contact mlaw.repository@umich.edu. 
DRAFT $11 / 14 / 12$

\author{
Double or Nothing: \\ A Tax Treaty for the $21^{\text {st }}$ Century \\ Reuven S. Avi-Yonah \\ The University of Michigan \\ Oz Halabi \\ The University of Michigan
}

\begin{abstract}
The current tax treaty network was developed in the 1920s and 1930s in order to prevent double residence/source taxation. This kind of double taxation rarely exists any more because most countries have adopted either an exemption system or a foreign tax credit regime in their domestic (non-treaty) law, which effectively prevents residence/source double taxation even in the absence of a treaty. Instead, as Tsilly Dagan has pointed out, the current treaties serve mostly to transfer revenue from the source country to the residence country. This suggests that treaties may be unnecessary because exemption from withholding taxes by source countries can be done unilaterally. However, in the era of globalization (post 1980), the treaties have developed two new functions, both of which apply primarily to individual taxpayers: First, to prevent double non-taxation by ensuring that withholding taxes are collected if there is no assurance of taxation by the residence country. Second, to enforce residence based taxation of individuals by having source countries provide information to residence countries about income derived by their residents in the source country. The paper proposes ways to update the US model treaty to reflect these new functions.
\end{abstract}


1. Introduction: What are Tax Treaties For?

Income tax treaties used to be called "Convention for the Avoidance of Double Taxation and the Prevention of Fiscal Evasion." Many treaties (and the US Model) still have that name, but the more up to date OECD model is now simply called "OECD Model Tax Convention on Income and Capital." This change in nomenclature may reflect a growing recognition that treaties no longer fulfill an important function in preventing double taxation, if they ever did so. The reason for this development is that, as Tsilly Dagan pointed out in her important article "The Tax Treaties Myth," tax treaties are not in fact needed to prevent double taxation. Almost every country in the world now either exempts foreign source income from tax altogether, or provides a foreign tax credit. Thus, the classic dilemma of how to prevent taxation of the same item of income by both the country where it originates (the source jurisdiction) and the country in which the recipient of the income resides (the residence jurisdiction) has largely been resolved without the need for tax treaties.

Dagan also points out that treaties can fulfill another function: By limiting the ability of source jurisdictions to tax active income to cases where the taxpayer has a permanent establishment in the source jurisdiction, and by reducing withholding taxes on the various categories of passive income, the treaties transfer revenue from source to residence jurisdictions. But it can be argued that even if this is accepted as a legitimate function (and Dagan as well as Eduardo Baistrocchi have questioned its legitimacy where investment flows are not balanced), tax treaties are not needed to achieve it because (a) most countries abide by some limitation on their ability to tax active income under domestic law, like the US requirement that such income be effectively connected with a US trade or business; (b) most countries unilaterally reduce withholding taxes on passive income whenever the income can be earned elsewhere, like the US portfolio interest exemption.

So what are tax treaties good for in the $21^{\text {st }}$ century? This article will argue that tax treaties are in fact superfluous for corporate taxpayers, and that it would be better to protect them from exorbitant source-country taxation by ceasing to exclude tax matters from the scope of bilateral investment treaties (BITs) since such treaties have much stronger dispute resolution mechanisms. For individual taxpayers, however, the article will argue that the treaties are useful as a global savings directive, i.e., that they help enforce residence-based taxation by applying a withholding tax where the taxpayer cannot show that she is a resident of a jurisdiction that levies the income tax, and providing for exchange of information in all other cases. The article will then propose revisions to the US model treaty congruent with this analysis.

2. Do Corporations Need Tax Treaties, or are BITs enough? 
The treaty articles of most relevance to corporate taxpayers are 5 (definition of the permanent establishment threshold), 7 (business profits), 9 (transfer pricing), and 10-13 (reduction of source taxation on dividends, interest, royalties and capital gains). However, all of these articles are arguably obsolete. Articles 5 and 7 are based on a world in which physical presence was essential for conducting business operations in a source country, and that is largely an obsolete concept. As the VAT experience has shown, it is possible to impose tax on both $\mathrm{B} 2 \mathrm{~B}$ and most $\mathrm{B} 2 \mathrm{C}$ transactions in electronic commerce without relying on physical presence, but only if the corporation cannot take its business elsewhere. Thus, we would argue that articles 5 and 7 , with all of their horrifying complexity, can be deleted without significantly impacting foreign direct investment (FDI). After all, multinational enterprises (MNEs) can almost always operate via subsidiaries rather than branches, in which case articles 5 and 7 are irrelevant. And if they are relevant, MNEs can usually withdraw from a country if it imposes unreasonable taxes on FDI, so that most countries refrain from doing so.

Articles 10-13 are likewise not needed for corporate taxpayers. Passive income can either be earned anywhere, like interest and some types of royalties and dividends, or it can be specific to rents earned in a particular country. In the first case, tax competition will ensure that the source country unilaterally refrain from levying a withholding tax, lest it be shifted to its own residents. In the second case, the MNE should be taxed since the rent derives from the source country.

That leaves article 9. But article 9 does not itself accomplish much, other than arguably enshrining the very problematic arm's length standard in the treaties. Article 9 does not even eliminate double source/source taxation, as shown by the Glaxo saga. All the actual work in transfer pricing is done by the OECD Guidelines, which are not part of the treaty. Moreover, if there is a transfer pricing double tax issue, the Mutual Agreement Procedure (MAP) is not very effective in resolving it, since the taxpayer cannot force a MAP.

Instead, there is a better solution for corporate taxpayers: eliminate them from the tax treaties altogether by redefining residents as only individuals. Then, to prevent egregious cases of tax discrimination and/or expropriation, income taxes should be included in the scope of BITs. BITs almost always apply to MNEs and have two significant advantages over tax treaties: First, they have a most favored nation (MFN) provision, so that they effectively form a multilateral network. Second, the taxpayer can force arbitration in a neutral panel and recover damages from the source country if the tax levied amounts to a regulatory taking or is discriminatory. Imagine in Glaxo if the company could have forced the US into arbitration. Would the IRS have been able to treat Glaxo differently than it did Smithkline Beecham, and would it have been able to extract $\$ 3.4$ billion in tax on income that had already been taxed in the UK? A neutral mandatory arbitration panel that the taxpayer can 
automatically appeal to is the best way to resolve such questions, as shown by Vodaphone's recent experience in India and by Occidental Petroleum's experience in Ecuador.

3. Tax Treaties as a Global Savings Directive

For individual taxpayers, the tax treaties function as a global savings directive. The EU savings directive gives countries a choice between imposing a withholding tax and cooperating with exchange of information. Similarly, by entering into a tax treaty with a jurisdiction, a country (a) confirms that the other country is not a tax haven and therefore is likely to impose income tax on its individual residents, and (b) cooperates in exchange of information to enable the residence jurisdiction to collect tax due from its own residents. If these two conditions are not met, there is no tax treaty, and the result is a withholding tax.

Unfortunately, countries also abolish withholding taxes unilaterally, even in situations where the payments go to tax havens, and refrain from collecting information on such payments. But these conditions (which are a function of domestic law, not of treaties) are changing as a result of enactments like FATCA, which has led to the first significant limit on harmful tax competition for portfolio investment since the misguided and destructive portfolio interest exemption was enacted in 1984 . We believe that withholding taxes outside the treaty context can be reinstated if this is done by mutual agreement among the US, EU and Japan (but not via OECD, where small countries have a veto).

4. A Proposed New US Model

\section{CONVENTION BETWEEN THE GOVERNMENT OF THE UNITED STATES OF AMERICA AND THE GOVERNMENT OF FOR THE PREVENTION OF FISCAL EVASION WITH RESPECT TO TAXES ON INCOME}

The Government of the United States of America and the Government of desiring to conclude a Convention for the prevention of fiscal evasion with respect to taxes on income, have agreed as follows:

Article 1

General Scope

1. This Convention shall apply only to individuals who are residents of one or both of the Contracting States, except as otherwise provided in the Convention.

2. This Convention shall not restrict in any manner any benefit now or hereafter accorded: 
a) by the laws of either Contracting State; or

b) by any other agreement to which the Contracting States are parties.

3. This Convention shall not affect the taxation by a Contracting State of its residents (as determined under Article 4 (Resident)) and its citizens. Notwithstanding the other provisions of this Convention, a former citizen or former long-term resident of a Contracting State may, for the period of ten years following the loss of such status, be taxed in accordance with the laws of that Contracting State.

4. An item of income, profit or gain derived through an entity that is fiscally transparent under the laws of either Contracting State shall be considered to be derived by a resident of a State to the extent that the item is treated for purposes of the taxation law of such Contracting State as the income, profit or gain of a resident.

Article 2

Taxes Covered

1. This Convention shall apply to taxes on income imposed on behalf of a Contracting State irrespective of the manner in which they are levied.

2. There shall be regarded as taxes on income all taxes imposed on total income, or on elements of income, including taxes on gains from the alienation of property.

3. The existing taxes to which this Convention shall apply are:

a) in the case of

b) in the case of the United States: the Federal income taxes imposed by the Internal Revenue Code (but excluding social security and unemployment taxes), and the Federal excise taxes imposed with respect to private foundations.

4. This Convention shall apply also to any identical or substantially similar taxes that are imposed after the date of signature of the Convention in addition to, or in place of, the existing taxes. The competent authorities of the Contracting States shall notify each other of any changes that have been made in their respective taxation or other laws that significantly affect their obligations under this Convention.

Article 3

General Definitions

1. For the purposes of this Convention, unless the context otherwise requires:

a) the term "person" includes an individual, an estate, a trust, a partnership, a company, and any other body of persons; 
b) the term "company" means any body corporate or any entity that is treated as a body corporate for tax purposes according to the laws of the state in which it is organized;

c) the terms "enterprise of a Contracting State" and "enterprise of the other Contracting State" mean respectively an enterprise carried on by a resident of a Contracting State, and an enterprise carried on by a resident of the other Contracting State; the terms also include an enterprise carried on by a resident of a Contracting State through an entity that is treated as fiscally transparent in that Contracting State;

d) the term "enterprise" applies to the carrying on of any business;

e) the term "business" includes the performance of professional services and of other activities of an independent character;

f) the term "international traffic" means any transport by a ship or aircraft, except when such transport is solely between places in a Contracting State;

g) the term "competent authority" means:

i) in — —

ii) in the United States: the Secretary of the Treasury or his delegate;

h) the term "___ " means;

i) the term "United States" means the United States of America, and includes the states thereof and the District of Columbia; such term also includes the territorial sea thereof and the sea bed and subsoil of the submarine areas adjacent to that territorial sea, over which the United States exercises sovereign rights in accordance with international law; the term, however, does not include Puerto Rico, the Virgin Islands, Guam or any other United States possession or territory;

j) the term "national" of a Contracting State means:

i) any individual possessing the nationality or 
citizenship of that State; and

ii) any legal person, partnership or association

deriving its status as such from the laws in force in that

State;

k) the term "pension fund" means any person

established in a Contracting State that is:

i) generally exempt from income taxation in that

State; and

ii) operated principally either:

A) to administer or provide pension or retirement benefits; or

B) to earn income for the benefit of one or more persons described in clause A).

2. As regards the application of the Convention at any time by a Contracting State any term not defined therein shall, unless the context otherwise requires, or the competent authorities agree to a common meaning pursuant to the provisions of Article 18 (Mutual Agreement Procedure), have the meaning which it has at that time under the law of that State for the purposes of the taxes to which the Convention applies, any meaning under the applicable tax laws of that State prevailing over a meaning given to the term under other laws of that State.

\section{Article 4}

\section{Resident}

1. For the purposes of this Convention, the term "resident of a Contracting State" means any individual who, under the laws of that State, is liable to tax therein by reason of his domicile, residence, citizenship, or any other criterion of a similar nature. This term, however, does not include any individual who is liable to tax in that State in respect only of income from sources in that State.

2. Where, by reason of the provisions of paragraph 1 , an individual is a resident of both Contracting States, then his status shall be determined as follows:

a) he shall be deemed to be a resident only of the State in which he has a permanent home available to him; if he has a permanent home available to him in both States, he shall be deemed to be a resident only of the State with which his personal and economic relations are closer (center of vital interests);

b) if the State in which he has his center of vital 
interests cannot be determined, or if he does not have a permanent home available to him in either State, he shall be deemed to be a resident only of the State in which he has an habitual abode;

c) if he has an habitual abode in both States or in neither of them, he shall be deemed to be a resident only of the State of which he is a national;

d) if he is a national of both States or of neither of them, the competent authorities of the Contracting States shall endeavor to settle the question by mutual agreement.

Article 5

\section{Dividends}

1. Dividends paid by a company that is incorporated in a Contracting State to a resident of the other Contracting State may be taxed in that other State.

2. However, such dividends may also be taxed in the Contracting State in which the company paying the dividends is incorporated and according to the laws of that State, but if the dividends are beneficially owned by a resident of the other Contracting State, except as otherwise provided, the tax so charged shall not exceed 15 percent of the gross amount of the dividends in all other cases.

This paragraph shall not affect the taxation of the company in respect of the profits out of which the dividends are paid.

3. For purposes of this Article, the term "dividends" means income from shares or other rights, not being debt-claims, participating in profits, as well as income that is subjected to the same taxation treatment as income from shares under the laws of the State in which the payer is incorporated.

\section{Article 6}

Interest

1. Interest arising in a Contracting State and beneficially owned by a resident of the other Contracting State may be taxed only in that other State.

2. Notwithstanding the provisions of paragraph 1 :

a) interest arising in that is determined with reference to receipts, sales, income, profits or other cash flow of the debtor or a related person, to any change in the value of any property of the debtor or a related person or to any dividend, partnership distribution or similar payment made by the debtor or a related person may be taxed in the Contracting State in which it arises, and according to the laws of that State, but if the beneficial owner is a resident of the other 
Contracting State, the interest may be taxed at a rate not exceeding 15 percent of the gross amount of the interest;

b) interest arising in the United States that is contingent interest of a type that does not qualify as portfolio interest under United States law may be taxed by the United States but, if the beneficial owner of the interest is a resident of the interest may be taxed at a rate not exceeding 15 percent of the gross amount of the interest; and

c) interest that is an excess inclusion with respect to a residual interest in a real estate mortgage investment conduit may be taxed by each State in accordance with its domestic law.

3. The term "interest" as used in this Article means income from debt-claims of every kind, whether or not secured by mortgage, and whether or not carrying a right to participate in the debtor's profits, and in particular, income from government securities and income from bonds or debentures, including premiums or prizes attaching to such securities, bonds or debentures, and all other income that is subjected to the same taxation treatment as income from money lent by the taxation law of the Contracting State in which the income arises. Income dealt with in Article 5 (Dividends) and penalty charges for late payment shall not be regarded as interest for the purposes of this Convention.

4. Where, by reason of a special relationship between the payer and the beneficial owner or between both of them and some other person, the amount of the interest, having regard to the debt-claim for which it is paid, exceeds the amount which would have been agreed upon by the payer and the beneficial owner in the absence of such relationship, the provisions of this Article shall apply only to the last-mentioned amount. In such case the excess part of the payments shall remain taxable according to the laws of each State, due regard being had to the other provisions of this Convention.

\section{Article 7 \\ Royalties}

1. Royalties arising in a Contracting State and beneficially owned by a resident of the other Contracting State may be taxed only in that other State.

2. The term "royalties" as used in this Article means:

a) payments of any kind received as a consideration for the use of, or the right to use, any copyright of literary, artistic, scientific or other work (including cinematographic films), any patent, trademark, design or model, plan, secret formula or process, or for information concerning industrial, commercial or scientific experience; and

b) gain derived from the alienation of any property described in subparagraph a), to the extent that such gain is contingent on the productivity, use, or disposition of the 
property.

3. Where, by reason of a special relationship between the payer and the beneficial owner or between both of them and some other person, the amount of the royalties, having regard to the use, right, or information for which they are paid, exceeds the amount which would have been agreed upon by the payer and the beneficial owner in the absence of such relationship, the provisions of this Article shall apply only to the lastmentioned amount. In such case the excess part of the payments shall remain taxable according to the laws of each Contracting State, due regard being had to the other provisions of the Convention.

\section{Article 8 \\ Gains}

1. Gains derived by a resident of a Contracting State that are attributable to the alienation of real property situated in the other Contracting State may be taxed in that other State.

2. For the purposes of this Article the term "real property situated in the other Contracting State" shall include:

a) real property;

b) where that other State is the United States, a United

States real property interest; and

c) where that other State is

i) shares, including rights to acquire shares, other than shares in which there is regular trading on a stock exchange, deriving their value or the greater part of their value directly or indirectly from real property referred to in subparagraph a) of this paragraph situated in ; and

ii) an interest in a partnership or trust to the extent that the assets of the partnership or trust consist of real property situated in or of shares referred to in clause i) of this sub-paragraph.

3. Gains from the alienation of any property other than property referred to in paragraphs 1 through 5 shall be taxable only in the Contracting State of which the alienator is a resident.

\section{Article 9}

Income From Employment

Subject to the provisions of Articles 10 (Directors' Fees), 12 (Pensions, Social Security, Annuities, Alimony, and Child Support) and 14 (Government Service), salaries, 
wages, and other similar remuneration derived by a resident of a Contracting State in respect of an employment shall be taxable only in that State unless the employment is exercised in the other Contracting State. If the employment is so exercised, such remuneration as is derived therefrom may be taxed in that other State.

\section{Article 10}

Directors' Fees

Directors' fees and other compensation derived by a resident of a Contracting State for services rendered in the other Contracting State in his capacity as a member of the board of directors of a company that is incorporated in the other Contracting State may be taxed in that other Contracting State.

Article 11

\section{Entertainers and Sportsmen}

1. Income derived by a resident of a Contracting State as an entertainer, such as a theater, motion picture, radio, or television artiste, or a musician, or as a sportsman, from his personal activities as such exercised in the other Contracting State may be taxed in that other State, except where the amount of the gross receipts derived by such entertainer or sportsman, including expenses reimbursed to him or borne on his behalf, from such activities does not exceed twenty thousand United States dollars $(\$ 20,000)$ or its equivalent in ___ for the taxable year of the payment.

2. Where income in respect of activities exercised by an entertainer or a sportsman in his capacity as such accrues not to the entertainer or sportsman himself but to another person, that income may be taxed in the Contracting State in which the activities of the entertainer or sportsman are exercised unless the contract pursuant to which the personal activities are performed allows that other person to designate the individual who is to perform the personal activities.

Article 12

Pensions, Social Security, Annuities, Alimony, and Child Support

1. a) Pensions and other similar remuneration beneficially owned by a resident of a Contracting State shall be taxable only in that State.

b) Notwithstanding subparagraph a), the amount of any such pension or remuneration arising in a Contracting State that, when received, would be exempt from taxation in that State if the beneficial owner were a resident thereof shall be exempt from taxation in the Contracting State of which the beneficial owner is a resident.

2. Notwithstanding the provisions of paragraph 1, payments made by a Contracting State under provisions of the social security or similar legislation of that State to a 
resident of the other Contracting State or to a citizen of the United States shall be taxable only in the first-mentioned State.

3. Annuities derived and beneficially owned by an individual resident of a Contracting State shall be taxable only in that State. The term "annuities" as used in this paragraph means a stated sum paid periodically at stated times during a specified number of years, or for life, under an obligation to make the payments in return for adequate and full consideration (other than services rendered).

4. Alimony paid by a resident of a Contracting State to a resident of the other Contracting State shall be taxable only in that other State. The term "alimony" as used in this paragraph means periodic payments made pursuant to a written separation agreement or a decree of divorce, separate maintenance, or compulsory support, which payments are taxable to the recipient under the laws of the State of which he is a resident.

5. Periodic payments, not dealt with in paragraph 4, for the support of a child made pursuant to a written separation agreement or a decree of divorce, separate maintenance, or compulsory support, paid by a resident of a Contracting State to a resident of the other Contracting State, shall be exempt from tax in both Contracting States.

Article 13

Pension Funds

1. Where an individual who is a resident of one of the States is a member or beneficiary of, or participant in, a pension fund that is a resident of the other State, income earned by the pension fund may be taxed as income of that individual only when, and, subject to the provisions of paragraph 1 of Article 12 (Pensions, Social Security, Annuities, Alimony and Child Support), to the extent that, it is paid to, or for the benefit of, that individual from the pension fund (and not transferred to another pension fund in that other State).

2. Where an individual who is a member or beneficiary of, or participant in, a pension fund that is a resident of one of the States exercises an employment or self-employment in the other State:

a) contributions paid by or on behalf of that individual to the pension fund during the period that he exercises an employment or self-employment in the other State shall be deductible (or excludible) in computing his taxable income in that other State; and

b) any benefits accrued under the pension fund, or contributions made to the pension fund by or on behalf of the individual's employer, during that period shall not be treated as part of the employee's taxable income and any such contributions shall be allowed as a deduction in computing the taxable income of his employer in that other State. 
The relief available under this paragraph shall not exceed the relief that would be allowed by the other State to residents of that State for contributions to, or benefits accrued under, a pension plan established in that State.

3. The provisions of paragraph 2 of this Article shall not apply unless:

a) contributions by or on behalf of the individual, or by or on behalf of the individual's employer, to the pension fund (or to another similar pension fund for which the first-mentioned pension fund was substituted) were made before the individual began to exercise an employment or self-employment in the other State; and

b) the competent authority of the other State has agreed that the pension fund generally corresponds to a pension fund established in that other State.

4. a) Where a citizen of the United States who is a resident of ___ exercises an employment in ___ the income from which is taxable in __ the contribution is borne by an employer who is a resident of ___ or by a permanent establishment situated in __ and the individual is a member or beneficiary of, or participant in, a pension plan established in

i) contributions paid by or on behalf of that individual to the pension fund during the period that he exercises the employment in , and that are attributable to the employment, shall be deductible (or excludible) in computing his taxable income in the United States; and

ii) any benefits accrued under the pension fund, or contributions made to the pension fund by or on behalf of the individual's employer, during that period, and that are attributable to the employment, shall not be treated as part of the employee's taxable income in computing his taxable income in the United States.

b) The relief available under this paragraph shall not exceed the lesser of:

i) the relief that would be allowed by the United States to its residents for contributions to, or benefits accrued under, a generally corresponding pension plan established in the United States; and 
ii) the amount of contributions or benefits that qualify for tax relief in

c) For purposes of determining an individual's eligibility to participate in and receive tax benefits with respect to a pension plan established in the United States, contributions made to, or benefits accrued under, a pension plan established in shall be treated as contributions or benefits under a generally corresponding pension plan established in the United States to the extent relief is available to the individual under this paragraph.

d) This paragraph shall not apply unless the competent authority of the United States has agreed that the pension plan generally corresponds to a pension plan established in the United States.

Article 14

Government Service

1. Notwithstanding the provisions of Articles 10 (Directors' Fees), 11 (Entertainers and Sportsmen) and 15 (Students and Trainees):

a) Salaries, wages and other remuneration, other than a pension, paid to an individual in respect of services rendered to a Contracting State or a political subdivision or local authority thereof shall, subject to the provisions of subparagraph b), be taxable only in that State;

b) such remuneration, however, shall be taxable only in the other Contracting State if the services are rendered in that State and the individual is a resident of that State who:

i) is a national of that State; or

ii) did not become a resident of that State solely for the purpose of rendering the services.

2. Notwithstanding the provisions of paragraph 1 of Article 12 (Pensions, Social Security, Annuities, Alimony, and Child Support):

a) any pension and other similar remuneration paid by, or out of funds created by, a Contracting State or a political subdivision or a local authority thereof to an individual in respect of services rendered to that State or subdivision or authority (other than a payment to which paragraph 2 of Article 12 applies) shall, subject to the provisions of subparagraph b), be taxable only in that State; 
b) such pension, however, shall be taxable only in the other Contracting State if the individual is a resident of, and a national of, that State.

3. The provisions of Articles 10 (Directors' Fees), 11 (Entertainers and Sportsmen) and 12 (Pensions, Social Security, Annuities, Alimony, and Child Support) shall apply to salaries, wages and other remuneration, and to pensions, in respect of services rendered in connection with a business carried on by a Contracting State or a political subdivision or a local authority thereof.

Article 15

Students and Trainees

1. Payments, other than compensation for personal services, received by a student or business trainee who is, or was immediately before visiting a Contracting State, a resident of the other Contracting State, and who is present in the first-mentioned State for the purpose of his full-time education or for his full-time training, shall not be taxed in that State, provided that such payments arise outside that State, and are for the purpose of his maintenance, education or training. The exemption from tax provided by this paragraph shall apply to a business trainee only for a period of time not exceeding one year from the date the business trainee first arrives in the first-mentioned Contracting State for the purpose of training.

2. A student or business trainee within the meaning of paragraph 1 shall be exempt from tax by the Contracting State in which the individual is temporarily present with respect to income from personal services in an aggregate amount equal to $\$ 9,000$ or its equivalent in [] annually. The competent authorities shall, every five years, adjust the amount provided in this subparagraph to the extent necessary to take into account changes in the U.S. personal exemption and the standard deduction.

3. For purposes of this Article, a business trainee is an individual who is temporarily in a Contracting State for the purpose of securing training required to qualify the individual to practice a profession or professional specialty.

Article 16

Other Income

Items of income beneficially owned by a resident of a Contracting State, wherever arising, not dealt with in the foregoing Articles of this Convention shall be taxable only in that State.

\section{Article 17}

Non-Discrimination

1. Nationals of a Contracting State shall not be subjected in the other Contracting State to any taxation or any requirement connected therewith that is more burdensome than the taxation and connected requirements to which nationals of that other State in the 
same circumstances, in particular with respect to residence, are or may be subjected. This provision shall also apply to persons who are not residents of one or both of the Contracting States. However, for the purposes of United States taxation, United States nationals who are subject to tax on a worldwide basis are not in the same circumstances as nationals of who are not residents of the United States.

2. The provisions of paragraphs 1 and 2 shall not be construed as obliging a Contracting State to grant to residents of the other Contracting State any personal allowances, reliefs, and reductions for taxation purposes on account of civil status or family responsibilities that it grants to its own residents.

3. Except where the provisions of paragraph 5 of Article 6 (Interest), or paragraph 4 of Article 7 (Royalties) apply, interest, royalties, and other disbursements paid by a corporation incorporated in a Contracting State to a resident of the other Contracting State shall, for the purpose of determining the taxable profits of the first-mentioned resident, be deductible under the same conditions as if they had been paid to a resident of the first-mentioned State. Similarly, any debts of a resident of a Contracting State to a resident of the other Contracting State shall, for the purpose of determining the taxable capital of the first-mentioned resident, be deductible under the same conditions as if they had been contracted to a resident of the first-mentioned State.

4. Enterprises of a Contracting State, the capital of which is wholly or partly owned or controlled, directly or indirectly, by one or more residents of the other Contracting State, shall not be subjected in the first-mentioned State to any taxation or any requirement connected therewith that is more burdensome than the taxation and connected requirements to which other similar enterprises of the first-mentioned State are or may be subjected.

5. Nothing in this Article shall be construed as preventing either Contracting State from imposing a tax as described in paragraph 8 of Article 5 (Dividends).

6. The provisions of this Article shall, notwithstanding the provisions of Article 2 (Taxes Covered), apply to taxes of every kind and description imposed by a Contracting State or a political subdivision or local authority thereof.

Article 18

Mutual Agreement Procedure

1. Where a person considers that the actions of one or both of the Contracting States result or will result for such person in taxation not in accordance with the provisions of this Convention, it may, irrespective of the remedies provided by the domestic law of those States, and the time limits prescribed in such laws for presenting claims for refund, present its case to the competent authority of either Contracting State.

2. The competent authority shall endeavor, if the objection appears to it to be justified and if it is not itself able to arrive at a satisfactory solution, to resolve the case by mutual agreement with the competent authority of the other Contracting State, with a view to the avoidance of taxation which is not in accordance with the Convention. Any agreement reached shall be implemented notwithstanding any time limits or other procedural limitations in the domestic law of the Contracting States. Assessment and collection 
procedures shall be suspended during the period that any mutual agreement proceeding is pending.

3. The competent authorities of the Contracting States shall endeavor to resolve by mutual agreement any difficulties or doubts arising as to the interpretation or application of the Convention. They also may consult together for the elimination of double taxation in cases not provided for in the Convention. In particular the competent authorities of the Contracting States may agree:

a) to the same attribution of income, deductions, credits, or allowances of an enterprise of a Contracting State;

b) to the same allocation of income, deductions, credits, or allowances between persons;

c) to the settlement of conflicting application of the Convention, including conflicts regarding:

i) the characterization of particular items of income;

ii) the characterization of persons;

iii) the application of source rules with respect to particular items of income;

iv) the meaning of any term used in the Convention;

v) the timing of particular items of income;

d) to advance pricing arrangements; and

e) to the application of the provisions of domestic law regarding penalties, fines, and interest in a manner consistent with the purposes of the Convention.

4. The competent authorities also may agree to increases in any specific dollar amounts referred to in the Convention to reflect economic or monetary developments.

5. The competent authorities of the Contracting States may communicate with each other directly, including through a joint commission, for the purpose of reaching an agreement in the sense of the preceding paragraphs.

\section{Article 19}

Exchange of Information and Administrative Assistance

1. The competent authorities of the Contracting States shall exchange such information as may be relevant for carrying out the provisions of this Convention or of the domestic laws of the Contracting States concerning taxes of every kind imposed by a Contracting State to the extent that the taxation thereunder is not contrary to the 
Convention, including information relating to the assessment or collection of, the enforcement or prosecution in respect of, or the determination of appeals in relation to, such taxes. The exchange of information is not restricted by paragraph 1 of Article 1 (General Scope) or Article 2 (Taxes Covered).

2. Any information received under this Article by a Contracting State shall be treated as secret in the same manner as information obtained under the domestic laws of that State and shall be disclosed only to persons or authorities (including courts and administrative bodies) involved in the assessment, collection, or administration of, the enforcement or prosecution in respect of, or the determination of appeals in relation to, the taxes referred to above, or the oversight of such functions. Such persons or authorities shall use the information only for such purposes. They may disclose the information in public court proceedings or in judicial decisions.

3. In no case shall the provisions of the preceding paragraphs be construed so as to impose on a Contracting State the obligation:

a) to carry out administrative measures at variance with the laws and administrative practice of that or of the other Contracting State;

b) to supply information that is not obtainable under the laws or in the normal course of the administration of that or of the other Contracting State;

c) to supply information that would disclose any trade, business, industrial, commercial, or professional secret or trade process, or information the disclosure of which would be contrary to public policy (ordre public).

4. If information is requested by a Contracting State in accordance with this Article, the other Contracting State shall use its information gathering measures to obtain the requested information, even though that other State may not need such information for its own purposes. The obligation contained in the preceding sentence is subject to the limitations of paragraph 3 but in no case shall such limitation be construed to permit a Contracting State to decline to supply information because it has no domestic interest in such information.

5. In no case shall the provisions of paragraph 3 be construed to permit a Contracting State to decline to supply information requested by the other Contracting State because the information is held by a bank, other financial institution, nominee or person acting in an agency or a fiduciary capacity or because it relates to ownership interests in a person.

6. If specifically requested by the competent authority of a Contracting State, the competent authority of the other Contracting State shall provide information under this Article in the form of depositions of witnesses and authenticated copies of unedited original documents (including books, papers, statements, records, accounts, and writings).

7. Each of the Contracting States shall endeavor to collect on behalf of the other Contracting State such amounts as may be necessary to ensure that relief granted by the 
Convention from taxation imposed by that other State does not inure to the benefit of persons not entitled thereto. This paragraph shall not impose upon either of the Contracting States the obligation to carry out administrative measures that would be contrary to its sovereignty, security, or public policy.

8. The requested State shall allow representatives of the requesting State to enter the requested State to interview individuals and examine books and records with the consent of the persons subject to examination.

8. [sic] The competent authorities of the Contracting States may develop an agreement upon the mode of application of this Article, including agreement to ensure comparable levels of assistance to each of the Contracting States, but in no case will the lack of such agreement relieve a Contracting State of its obligations under this Article.

Article 20

Members of Diplomatic Missions and Consular Posts

Nothing in this Convention shall affect the fiscal privileges of members of diplomatic missions or consular posts under the general rules of international law or under the provisions of special agreements.

Article 21

Entry Into Force

1. This Convention shall be subject to ratification in accordance with the applicable procedures of each Contracting State, and instruments of ratification will be exchanged as soon thereafter as possible.

2. This Convention shall enter into force on the date of the exchange of instruments of ratification, and its provisions shall have effect:

a) in respect of taxes withheld at source, for amounts paid

or credited on or after the first day of the second month next

following the date on which the Convention enters into force;

b) in respect of other taxes, for taxable periods beginning

on or after the first day of January next following the date on

which the Convention enters into force.

3. Notwithstanding paragraph 2, the provisions of Article 19 (Exchange of Information and Administrative Assistance) shall have effect from the date of entry into force of this Convention, without regard to the taxable period to which the matter relates.

Article 22

Termination

This Convention shall remain in force until terminated by a Contracting State. Either Contracting State may terminate the Convention by giving notice of termination to the other Contracting State through diplomatic channels. In such event, the Convention shall cease to have effect: 
a) in respect of taxes withheld at source, for amounts paid or credited after the expiration of the 6 month period beginning on the date on which notice of termination was given; and

b) in respect of other taxes, for taxable periods beginning on or after the

expiration of the 6 month period beginning on the date on which notice of termination was given.

In witness whereof, the undersigned, being duly authorized thereto by their respective Governments, have signed this Convention.

Done at ___ in duplicate, in the English and languages, both texts being equally authentic, this day of 20

FOR THE GOVERNMENT OF THE UNITED STATES OF AMERICA: FOR THE GOVERNMENT OF

5. Conclusion 